\title{
Effect of foliar application of boron trioxide and zinc oxide nanoparticles on leaves chemical composition, yield and fruit quality of Olea europaea L. Cv. Picual
}

Esmail A. E. Genaidy ${ }^{1 *}$ (D) Nazmy Abd-Alhamid², Hassan S. A. Hassan ${ }^{1}$, Ahmed M. Hassan ${ }^{1}$ and Laila F. Hagagg ${ }^{1}$

\begin{abstract}
Background and objective: Olive tree is one of the most important and a widely distributed tree grown in many arid and semi-arid areas of the world. The production of olive in these areas is generally low due to the poor soil fertility. Zinc is one of the essential micronutrients for plants, and its deficiency is common in many crops. Boron deficiency is also a common micronutrient problem in agriculture, which results in reducing of yield production and quality. Nanotechnology has emerged as one of the most innovative scientific field in agriculture. So the objective of this work is determine the appropriate concentration of nano-zinc and nano-boron to reach the best olive fruits yield and improve its chemical and morphological traits.
\end{abstract}

Materials and methods: The present investigation has been made during two successive seasons of 2017 and 2018 in a private orchard located at Ismailia governorate, Egypt, to study the effect of foliar application of boron nanoparticles at a rate of 10 and $20 \mathrm{ppm}$ and zinc nanoparticles at a rate of 100 and $200 \mathrm{ppm}$ on leaf chemical composition, yield, and fruit quality of Picual olive tree.

Results: The application of boron and zinc nanoparticles in different concentration was able to effect on the qualitative and quantitative characteristics of Picual cultivar in the first and second seasons, respectively, compared with the control treatment leaves mineral content and pigments, fruit set percent, fruit drop percent, fruits yield, fruit physical, and chemical characteristics. Moreover, spraying Picual cultivar with nano-boron at 20 ppm + nanozinc at 200 ppm (T8) is the best treatment in this study to obtain the maximum final fruit set which led to harvest the maximum fruits yield with the high seed oil percentage and low acidity in the first and second seasons, respectively.

Conclusion: It could recommend that spraying Picual olive trees with nano-boron at $20 \mathrm{ppm}+$ nano-zinc at 200 ppm is the best treatment in this study to obtain the maximum final fruit set which led to harvest the maximum fruits yield with the high seed oil percentage and low acidity.

Keywords: Olive (Olea europaea L.), Picual cultivar, Nanoparticles, Leaf traits, Fruit traits, Quality traits, Oil content, Oil chemical traits

\footnotetext{
*Correspondence: esmil_nrc@yahoo.com

${ }^{1}$ Pomology Department, National Research Centre, 33 El Bohouth St, Cairo

12622, Egypt

Full list of author information is available at the end of the article
}

\section{Springer Open}

(c) The Author(s). 2020 Open Access This article is licensed under a Creative Commons Attribution 4.0 International License, which permits use, sharing, adaptation, distribution and reproduction in any medium or format, as long as you give appropriate credit to the original author(s) and the source, provide a link to the Creative Commons licence, and indicate if changes were made. The images or other third party material in this article are included in the article's Creative Commons licence, unless indicated otherwise in a credit line to the material. If material is not included in the article's Creative Commons licence and your intended use is not permitted by statutory regulation or exceeds the permitted use, you will need to obtain permission directly from the copyright holder. To view a copy of this licence, visit http://creativecommons.org/licenses/by/4.0/. 


\section{Introduction}

Olea europaea L., family Oleaceae, is one of the most important and a widely distributed tree grown in many arid and semi-arid areas of the world. The production of olive in these areas is generally low due to poor soil fertility. In the Near East and North Africa countries, the area cultivated with olives was $3,772,989$ ha, and olive production was $4,044,696 \mathrm{MT}$. Oil production was 556, 354 T (FAO, 2010). Tunisia is the largest southern Mediterranean countries producing olive and olive oil. Tunisia is the second largest country in the world after the European Union and the fourth post country after Spain, Italy, and Greece (Gharbi et al., 2014). Now, according to the latest statistics of the Egyptian Ministry of Agriculture in 2012, the total cultivated land with olive is $202,743 \mathrm{fed}$., $14,353 \mathrm{fed}$. of this area in the old land, and $188,390 \mathrm{fed}$. in the new land. The total production is $563,070 \mathrm{~T}$; $76,017 \mathrm{~T}$ are in old land while 487,053 $\mathrm{T}$ in new land (El-Hassanin et al., 2015). Pereira et al. (2018) reported that total cultivated land with olive in Egypt was 139,000 ha which gave 522,710 ton.

Olive farming requires efficient fertilizer management, which minimizes the hazards of excessive mineral fertilizers due to their negative environmental impact and maximizes the economic feasibility and cost efficiency of fertilization (Gastal and Lemaire, 2002).

Nanotechnology has emerged as one of the most innovative scientific field in agriculture, which has at least one dimension ranging from one to $100 \mathrm{~nm}$. It provides an opportunity to develop improved systems for monitoring environmental conditions and delivering nutrients or pesticides as appropriate, improve our understanding of the biology of different crops, and thus potentially enhance yields or nutritional values. Besides, it can offer routes to added value crops or environmental remediation. The science of nanotechnology can work at the atomic, molecular, and even sub-molecular levels to create and use material structures, devices, and systems with new properties and functions (Jha et al., 2011).

The microelements that the plant needs in small amounts play an important role in the metabolic processes that take place inside the plant. Zinc is one of the essential micronutrients for plants, and its deficiency is common in many crops (Marschner, 2012 and OjedaBarrios et al., 2014). Zinc is required for the activity of different enzymes, including dehydrogenases, aldolases, iso-merases, transphosphorylases, RNA, and DNA polymerases, and involved in the synthesis of tryptophan, cell division, maintenance of membrane structure, and photosynthesis, and acts as regulatory cofactor in protein synthesis (Marschner, 2012). Boron (B) deficiency is also a common micronutrient problem in agriculture, which results in yield reductions and impaired crop quality (Barker and Pilbeam, 2007). Boron plays avid of role in plants; it has positive effects on the germination of pollen grains, the elongation of pollen tube, fruit set, and yield and is also indirectly responsible for the activation of dehydrogenase enzymes, sugar translocation, nucleic acids, and plant hormones (El-Sheikh et al., 2007 and Marschner, 2012).

Therefore, this work is aimed to investigate the effect of spraying different concentrations of nano-boron and zinc on leaf, fruit yield, and quality of olive.

\section{Materials and methods}

This study was carried out during two successive seasons (2017 and 2018) in a private orchard located at Ismailia governorate, Egypt. The study was conducted on 8 years old olive trees of Picual cv., planted at $4 \times 6 \mathrm{~m}$ apart grown in sandy soil, under drip irrigation system. The selected trees were uniformed in shape and received the common horticultural practices. The orchard soil analysis is given in Table 1, and the irrigation water analysis is given in Table 2 according to procedures which are outlined by Wild et al. (1985).

\section{Chemical synthesis of zinc oxide ( $\mathrm{ZnO}$ ) nanoparticles}

The transmission electron microscopy picture of nanoparticles of zinc oxide is presented in Fig. 1. Zinc sulfate heptahydrate and sodium hydroxide will be used in the experiments. To the aqueous solution of zinc sulfate, sodium hydroxide solution will be added slowly drop wise in a molar ratio of 1:2 under vigorous stirring, and the stirring will be continued for $12 \mathrm{~h}$. The precipitate obtained will be filtered and washed thoroughly with deionized water. The precipitate will be dried in an oven at $100{ }^{\circ} \mathrm{C}$ and ground to fine powder using agate mortar (Mohan et al., 2013).

Table 1 Physical and chemical properties of the orchard soil

\begin{tabular}{llll}
\hline Parameters & \multicolumn{3}{l}{ Depth of simple $(\mathrm{cm})$} \\
\cline { 2 - 4 } & Surface sample & $30 \mathrm{~cm}$ depth & $60 \mathrm{~cm}$ depth \\
\hline $\mathbf{p H}$ & 8.02 & 8.70 & 8.11 \\
EC(dSm-1) & 3.80 & 0.80 & 1.70 \\
$\mathbf{C a}^{++}$ & Soluble cations (meq) $)$ & 3.00 \\
$\mathbf{M g}^{++}$ & 6.00 & 2.50 & 1.50 \\
$\mathbf{N a}^{+}$ & 4.00 & 1.50 & 12.90 \\
$\mathbf{K}^{+}$ & 28.60 & 4.40 & 0.78 \\
& 0.12 & 0.14 & \\
$\mathbf{H C O}^{-}$ & Soluble anions (meq) & 2.00 \\
$\mathbf{C l}^{-}$ & 4.40 & 2.40 & 13.00 \\
$\mathbf{S O}_{\mathbf{4}}{ }^{+}$ & 27.20 & 5.00 & 3.18 \\
\hline
\end{tabular}


Table 2 Chemical characteristics of the irrigated water used in present study

\begin{tabular}{ll}
\hline Parameters & Values \\
\hline $\mathrm{pH}$ & 7.49 \\
$\mathrm{EC}(\mathrm{dSm}-1)$ & 4.40 \\
Soluble cations (meq/l) & \\
$\mathrm{Ca}++$ & 7.50 \\
$\mathrm{Mg}++$ & 5.00 \\
$\mathrm{Na}+$ & 33.1 \\
$\mathrm{~K}+$ & 0.16 \\
$\mathrm{Soluble}$ anions (meq/l) & \\
$\mathrm{HCO}_{3}^{-}$ & 1.60 \\
$\mathrm{Cl}^{-}$ & 40.00 \\
$\mathrm{SO}_{4}^{-2}$ & 4.16 \\
\hline
\end{tabular}

\section{Physical synthesis of boron trioxide nanoparticles by ball milling}

The transmission electron microscopy picture of nanoparticles of boron trioxide is presented in Fig. 2. Boron trioxide is produced by heating boric acid above $\sim 300$ ${ }^{\circ} \mathrm{C}$. Boric acid will initially decompose into steam, $\left(\mathrm{H}_{2} \mathrm{O}\right)$ and metaboric acid $\left(\mathrm{HBO}_{2}\right)$, at around $170{ }^{\circ} \mathrm{C}$, and further heating above $300{ }^{\circ} \mathrm{C}$ will produce more steam and boron trioxide (Kocakuşak et al., 1996).

The reactions are as follows:

$$
\mathrm{H}_{3} \mathrm{BO}_{3} \rightarrow \mathrm{HBO}_{2}+\mathrm{H}_{2} \mathrm{O} 2 \mathrm{HBO}_{2} \rightarrow \mathrm{B}_{2} \mathrm{O}_{3}+\mathrm{H}_{2} \mathrm{O}
$$

In this work, an attempt has been made to modify the microsized $\mathrm{B}_{2} \mathrm{O}_{3}$ powder into nanosized $\mathrm{B}_{2} \mathrm{O}_{3}$ powder using a ball mill according to (Alizadeh et al., 2015). The sample was taken out after $2 \mathrm{~h}$ of milling, and it was characterized for the crystallite size by transmission electron microscopy. The size of the nanostructure of particles for the total duration of $2 \mathrm{~h}$ was in the range of 20 to $50 \mathrm{~nm}$, and the shape of particles was round.

This experiment was designed to study the effect of spraying Picual olive trees with nano-boron and nanozinc at different concentrations (27 trees for all treatments) during two studied seasons as follows:

$$
\begin{aligned}
& \text { T0-control treatment (spray with distilled water only) } \\
& \text { T1-nano-boron at } 10 \mathrm{ppm} \\
& \text { T2-nano-boron at } 20 \mathrm{ppm} \\
& \text { T3-nano-zinc at } 100 \mathrm{ppm} \\
& \text { T4-nano-zinc at } 200 \mathrm{ppm}
\end{aligned}
$$

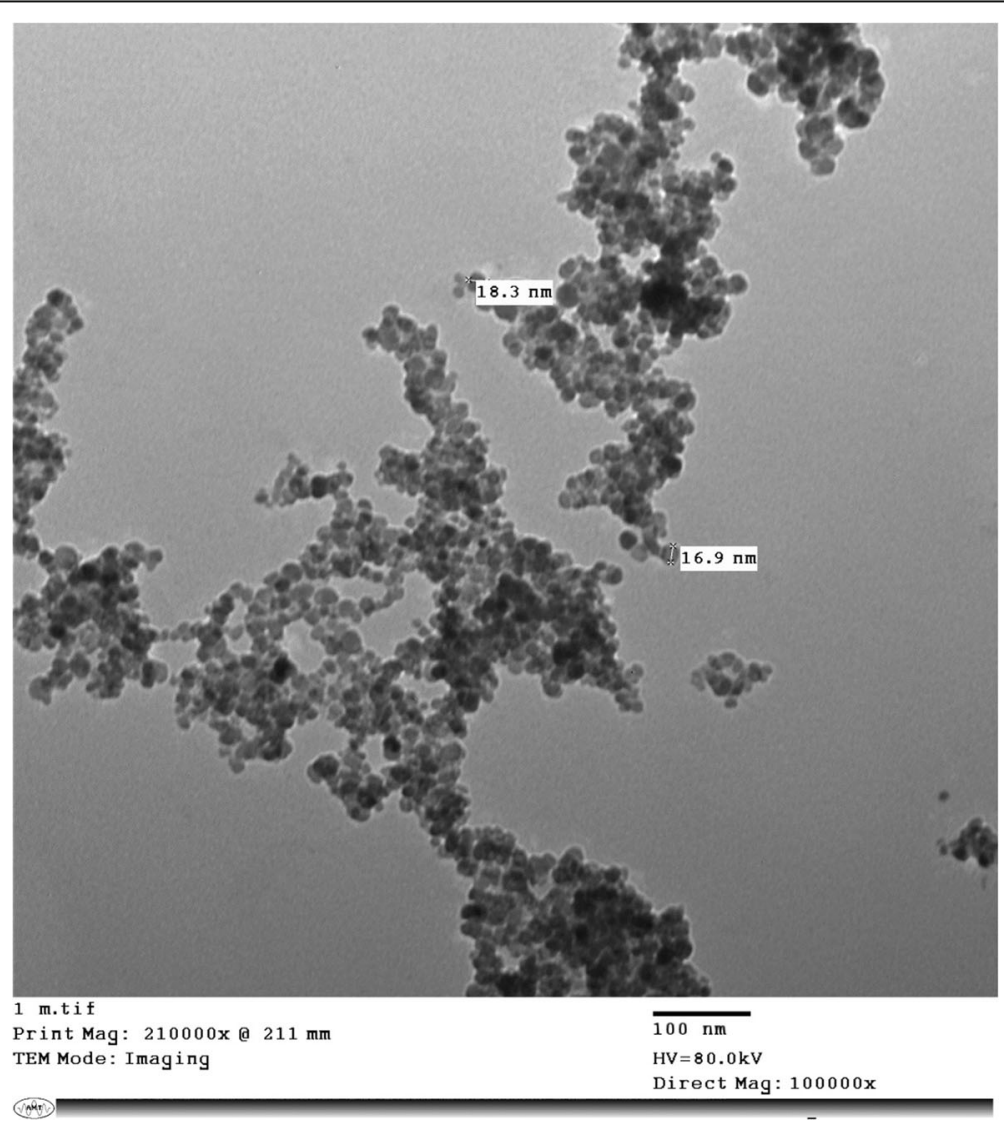

Fig. 1 Nanoparticles of zinc oxide composition average size of $17 \mathrm{~nm}$ (range from 16 to $18 \mathrm{~nm}$ ) 


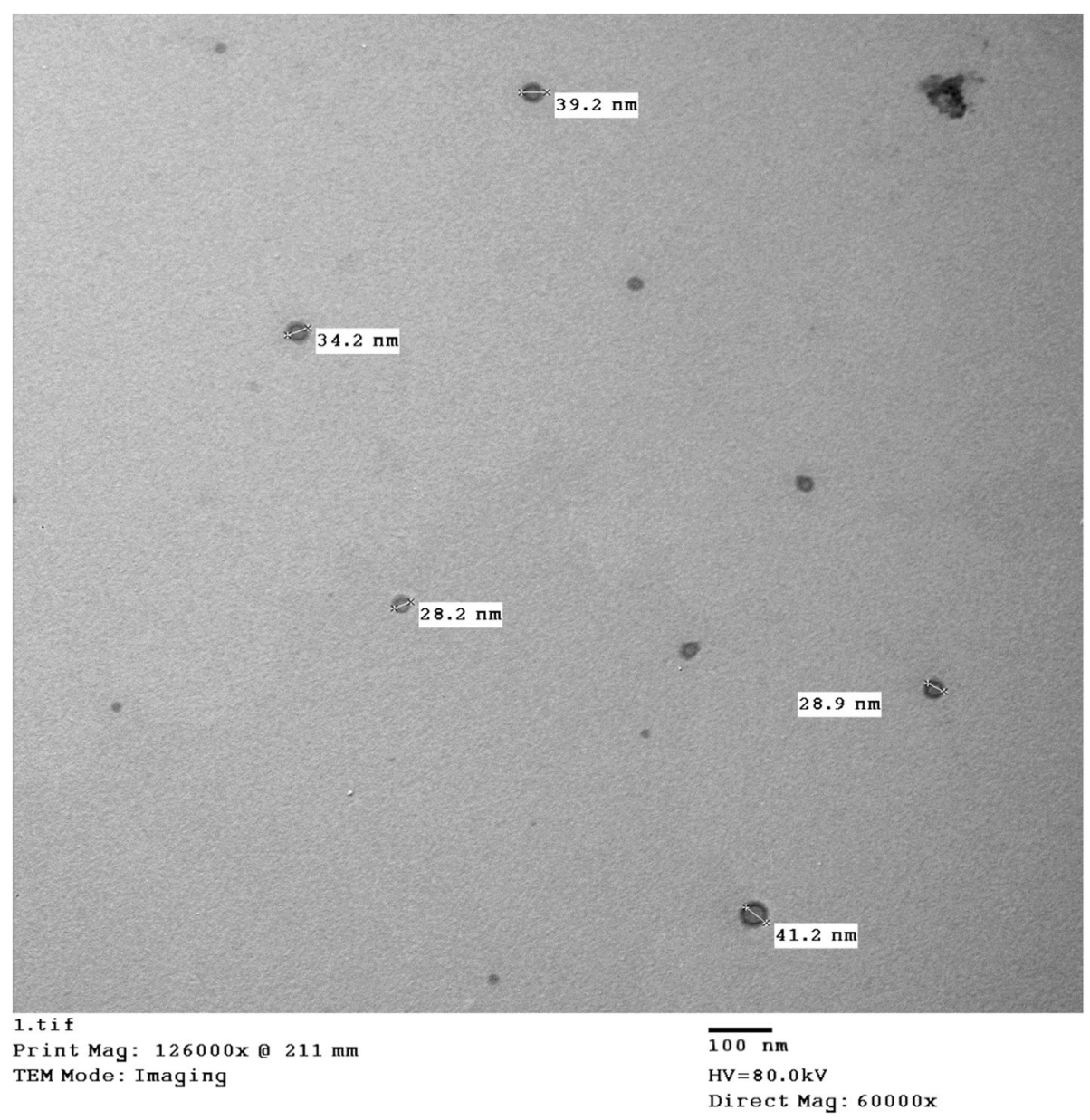

Fig. 2 Nanoparticles of boron trioxide composition average size $35 \mathrm{~nm}$ (range from 28 to $41 \mathrm{~nm}$ )

T5-nano-boron at $10 \mathrm{ppm}+$ nano-zinc at $100 \mathrm{ppm}$ T6-nano-boron at $10 \mathrm{ppm}+$ nano-zinc at $200 \mathrm{ppm}$ T7-nano-boron at $20 \mathrm{ppm}+$ nano-zinc at $100 \mathrm{ppm}$ T8-nano-boron at $20 \mathrm{ppm}+$ nano-zinc at $200 \mathrm{ppm}$

All treatments were applied at three different dates, i.e., the first one at mid of December, the second before the flowering (during March), and the third one during full bloom (April). Each treatment was represented by three replicates (one tree per replicate) which were chosen randomly on early October of each season; twenty healthy 1-year-old branches well distributed around the canopy were randomly selected and labeled ( 5 branches for each direction) for carrying out the following measurements:

\section{Leaf traits}

Leaves needed were randomly sampled from the previously labeled branches per each tree/replicate on the second week of September, whereas 2-3 leaves from every branch (4th and 5th leaves from the branch base) were picked then mixed as a composite for carrying out the following chemical analysis:

Leaf pigments Pigments, i.e., chlorophyll a, b, and carotene as $(\mathrm{mg} / \mathrm{g} \mathrm{f.w})$ were colormetrically determined in fresh leaf samples at wave length of 660, 640, and 440 $\mathrm{nm}$ for chlorophyll a, b, and carotene, respectively, according to Wettestien (1957).

Leaves mineral content Leaves sample from each tree/ replicate was separately oven dried at $70{ }^{\circ} \mathrm{C}$ till constant weight and then grounded for determination the following nutrient elements (Percentage from the dry weight):

Nitrogen percentage was estimated using the modified micro Kjeldahl method as lined by Pregl (1945).

Phosphorus percentage was estimated as described by Chapman and Pratt (1961).

Potassium percentage was determined flamephotometerically according to Brown and Lilleland (1946). 
Iron and zinc as ppm was determined spectrophotometerically using atomic absorption (Model, spectronic $21 \mathrm{D}$ ) as described by Jackson (1973).

Boron as ppm was determined by the curcumin method by Dible et al. (1954).

\section{Fruit set and fruit drop}

Fruit set percentage as number of fruits/meter at two times first after 20 days from full bloom as initial fruit set and the second 60 days after full bloom as final fruit set according to Fernandez and Gomez (1985). Final fruit set and fruit drop percentages were estimated as follows:

Initial fruit set $(\%)=\{$ Total number of set fruit (20 days after full bloom) /shoot $\} \times 100 /$ (Total number of flowers/shoot)

Final fruit set $(\%)=\{$ Total number of set fruit ( 60 days after full bloom $)$ /shoot $\} \times 100 /$ (Total number of flowers $/$ shoot

Fruit drop $(\%)=[($ initial fruit set-final fruit set $) /$ initial fruit set $] \times 100$

\section{Fruit yield}

Fruits were harvested at the ripening stage on the end of October in 2017 and 2018 years. Each individual tree was harvested manually, and the weight of fruits/tree for all trees was measured. Average yield $(\mathrm{kg}) /$ tree was determined for each treatment.

\section{Fruit morphological traits}

Thirty fruits per each tree were randomly selected for carrying out the fruit quality measurements:

Fruit weight It was determined by weighing the samples (30 fruits) by ordinary balance with $0.01 \mathrm{~g}$ sensitivity, and average weight per fruit was calculated.

Pulp weight It was determined by weighing the samples (30 fruits and their seeds), and average weight of pulp was calculated.

Pulp/seed ratio Values were calculated by dividing the weight of the pulp over the weight of the seed.

Fruit length $(\mathbf{c m})$ It was measured by digital caliper for length the sample (30 fruits), and the average weight of pulp was calculated.

Fruit diameter $(\mathbf{c m})$ It was measured by digital caliper for the diameter of the sample (30 fruits), and average weight of pulp was calculated.

\section{Fruit chemical traits}

Fruit oil content percentage (\%) Oil percentage was determined in the fruit flesh on dry weight basis using Soxhlet oil extraction apparatus with hexane $60-80{ }^{\circ} \mathrm{C}$ boiling point, according to Banat et al. (2013).

Acid value of oil It was determined according to the Dieffenbacker and Pocklington (1992), since $5 \mathrm{~g}$ of oil was accurately weighed in a $250-\mathrm{ml}$ dry conical flask with about $100 \mathrm{ml}$ of neutralized $50 \%$ ethanol $+50 \%$ petroleum ether to dissolve the oily sample. The acidity of the sample was determined by titration with $0.1 \mathrm{~N}$ of potassium hydroxide solution in the presence of phenolphthalein as an indicator. The acid value was calculated according to the following equation.

$$
\text { Acid percentage }=\frac{\mathrm{V} \times \mathrm{N} \times 5.61 \times 100}{\text { Sample weight }}
$$

where $V=$ volume of $\mathrm{KOH}$ solution and $N=$ normality of potassium hydroxide solution.

The peroxide value of oil The peroxide value was determined according to Jacobs (1959) by dissolving $5 \mathrm{~g}$ of the oil in a mixture consisting of $60 \%$ glacial acetic acid $+40 \%$ chloroform. The solution was treated with approximately $0.5 \mathrm{ml}$ of a saturated solution of potassium iodide in a glass Stoppard flask. The flask was shacked in rotary for exactly $2 \mathrm{~min}$, after which $30 \mathrm{ml}$ of distilled water was added, and the liberated iodine was titrated with $0.01 \mathrm{~N}$ sodium thiosulfate using $1 \%$ of the starch solution as external indicator.

The results were calculated in mill moles per kilogram oil according to the following equation.

$$
\text { Peroxide value }=\frac{0.5 \times \mathrm{N} \times \mathrm{V} \times 100}{\text { Sample weight }}
$$

where $N=$ normality of sodium thiosulfate solution and $V=$ volume in milliter of sodium thiosulfate needed for titration.

Iodine value of oil The degree of the instauration of oil was determined by measuring the amount of halogen absorbed by the oil as stated in Dieffenbacker and Pocklington (1992) since $0.1-0.5 \mathrm{~g}$ of oil was dissolved in 10 $\mathrm{ml}$ of chloroform, and $25 \mathrm{ml}$ of Hanus iodine solution was added. After $30 \mathrm{~min}, 10 \mathrm{ml}$ of $15 \%$ potassium iodide solution and $100 \mathrm{ml}$ of freshly boiled cooled distilled water were added. The liberated iodine was titrated with $0.1 \mathrm{~N}$ of sodium thiosulfate using the starch indicator. 
Iodine value $=\frac{\left(\mathrm{V}_{1}-\mathrm{V}_{2}\right) \times \mathrm{N} \times 12.69}{\text { Sample weight }}$

where $N=$ normality of sodium thiosulfate solution, $V_{1}=$ volume in milliliter of sodium thiosulfate needed for titration blank, and $V_{2}=$ volume in milliter of sodium thiosulfate needed for titration sample.

\section{Experimental design and statistical analysis}

The experimental layout was a randomized complete block design (RCBD) with three replicates for each treatment. All obtained data during both 2017 and 2018 experimental seasons were subjected to analysis of variances (ANOVA) according to Snedecor and Cochran (1980) using the MSTAT program. Least significant ranges (LSR) were used to compare between means of treatments according to Duncan (1955) at the probability of $5 \%$.

\section{Results}

\section{Leaf pigments}

The results in Table 3 showed that trees sprayed with nano-boron at $10 \mathrm{ppm}+$ nano-zinc at $200 \mathrm{ppm}$ (T6) gave the highest value of chlorophyll $(1.70 \mathrm{mg} / \mathrm{g} \mathrm{f.w})$ in the first season. Otherwise, in the second season spraying nano-boron at $20 \mathrm{ppm}+$ nano-zinc at $200 \mathrm{ppm}$ (T8), nano-boron at $10 \mathrm{ppm}+$ nano-zinc at $200 \mathrm{ppm}$ (T6), and nano-boron at $10 \mathrm{ppm}+$ nano-zinc at $100 \mathrm{ppm}$ (T5) recorded the maximum values $(1.64,1.63$, and $1.61 \mathrm{mg} /$ g, respectively, f.w) compared with the other treatments. On the other side, spraying with nano-boron at $10 \mathrm{ppm}$ (T1) exhibited the minimum leaf chlorophyll content $(1.03 \mathrm{mg} / \mathrm{g} \mathrm{f.w})$ with insignificant differences between $\mathrm{T} 0, \mathrm{~T} 1, \mathrm{~T} 3$, and $\mathrm{T} 7$, respectively, in the first season. Meanwhile, the control trees gave the lowest value (1.32 $\mathrm{mg} / \mathrm{g}$ f.w) with insignificant differences between T0, T2, $\mathrm{T} 3$, and T7, respectively, in the second season.
The results presented in the Table 3 indicated that leaf chlorophyll b content was affected by conducted treatments. As for tree spraying with nano-boron at $10 \mathrm{ppm}$ + nano-zinc at $100 \mathrm{ppm}$ (T5) and nano-boron at $20 \mathrm{ppm}$ + nano-zinc at $200 \mathrm{ppm}$ (T8) recorded the largest values in this respect, since there were 0.59 and $0.59 \mathrm{mg} / \mathrm{g}$ f.w and 0.59 and $0.58 \mathrm{mg} / \mathrm{g}$ f.w in the first and second seasons, respectively. Meanwhile, on the other side, the lowest chlorophyll b content was found with nano-zinc at $100 \mathrm{ppm}$ (T3) $(0.37 \mathrm{mg} / \mathrm{g}$ f.w $)$ in the first season and control treatment $(0.47 \mathrm{mg} / \mathrm{g}$ f.w $)$ in the second seasons, respectively.

The results in Table 3 showed that different treatments led to significant differences in leaf content of carotene in both seasons. Spraying with nano-boron at $20 \mathrm{ppm}$ (T2) and spraying with nano-boron at $10 \mathrm{ppm}+$ nano-zinc at $100 \mathrm{ppm}$ (T5) produced the highest values of carotene content $(0.53$ and $0.75 \mathrm{mg} / \mathrm{g}$ f.w for both treatment, respectively) in the first and second seasons, respectively. Furthermore, spraying trees with nanoboron at $10 \mathrm{ppm}$ (T1) gave the minimum value of carotene content $(0.39 \mathrm{mg} / \mathrm{g}$ f.w $)$ with insignificant differences between $\mathrm{T} 1$ and $\mathrm{T} 6$ in this regard in the first season, while in the second one, untreated trees (control) exhibited the minimum value $(0.66 \mathrm{mg} / \mathrm{g}$ f.w $)$ in this respect with insignificant differences between T0, T1, $\mathrm{T} 2$, T3, T6, and T7, respectively.

\section{Leaf mineral contents}

It is clear from the results in Table 4 that the most different spraying treatments significantly increased the leaf percentage of nitrogen than the control treatment during both seasons, respectively. Trees sprayed with nanoboron at $10 \mathrm{ppm}+$ nano-zinc at $100 \mathrm{ppm}$ (T5) gave the highest value (1.91 and 2.06\%) in the first and second seasons, respectively. On the other contrary, the control trees gave the minimum leaf percentage of nitrogen

Table 3 Effect of foliar application of $\mathrm{B}_{2} \mathrm{O}_{3}$ and $\mathrm{ZnO}$ nanoparticles on leaf pigments of Picual cultivar in 2017 and 2018 seasons

\begin{tabular}{|c|c|c|c|c|c|c|}
\hline \multirow[t]{2}{*}{ Treat. } & \multicolumn{2}{|c|}{ Chlorophyll a (mg/g f.w) } & \multicolumn{2}{|c|}{ Chlorophyll b (mg/g f.w) } & \multicolumn{2}{|c|}{ Carotene (mg/g f.w) } \\
\hline & 2017 & 2018 & 2017 & 2018 & 2017 & 2018 \\
\hline TO & $1.33 \mathrm{bcd}$ & $1.32 \mathrm{~d}$ & $0.47 \mathrm{e}$ & $0.47 d$ & 0.42 ef & $0.66 \mathrm{~d}$ \\
\hline $\mathrm{T} 1$ & $1.03 \mathrm{~d}$ & $1.55 \mathrm{~b}$ & $0.56 \mathrm{~b}$ & $0.56 \mathrm{ab}$ & $0.39 \mathrm{~g}$ & $0.69 \mathrm{~cd}$ \\
\hline $\mathrm{T} 2$ & $1.49 a b c$ & $1.37 \mathrm{~cd}$ & $0.54 \mathrm{bc}$ & $0.50 \mathrm{c}$ & $0.53 a$ & $0.68 d$ \\
\hline T3 & $1.06 \mathrm{~d}$ & $1.33 \mathrm{~cd}$ & $0.37 f$ & $0.50 \mathrm{c}$ & $0.50 \mathrm{~b}$ & $0.68 d$ \\
\hline T4 & $1.40 \mathrm{abc}$ & $1.40 \mathrm{C}$ & $0.52 \mathrm{~cd}$ & $0.52 \mathrm{c}$ & $0.44 d$ & $0.72 b c$ \\
\hline T5 & $1.63 \mathrm{ab}$ & $1.61 \mathrm{ab}$ & $0.59 a$ & $0.59 \mathrm{a}$ & $0.43 d$ & $0.75 a$ \\
\hline T6 & $1.70 \mathrm{a}$ & $1.63 \mathrm{a}$ & $0.58 \mathrm{a}$ & $0.56 \mathrm{~b}$ & $0.40 \mathrm{fg}$ & $0.69 \mathrm{~cd}$ \\
\hline T7 & $1.27 \mathrm{~cd}$ & $1.33 \mathrm{~cd}$ & $0.50 \mathrm{~d}$ & $0.50 \mathrm{c}$ & $0.42 \mathrm{de}$ & $0.67 d$ \\
\hline T8 & $1.65 \mathrm{ab}$ & $1.64 \mathrm{a}$ & $0.59 \mathrm{a}$ & $0.58 \mathrm{a}$ & $0.46 c$ & $0.73 a b$ \\
\hline
\end{tabular}

Mean in each column with similar letters is not significantly different at $5 \%$ level

T1, nano-boron at 10 ppm; T2, nano-boron at 20 ppm; T3, nano-zinc at 100 ppm; T4, nano-zinc at 200 ppm; T5, nano-boron at 10 ppm + nano-zinc at 100 ppm; T6, nano-boron at 10 ppm + nano-zinc at 200 ppm; T7, nano-boron at 20 ppm + nano-zinc at 100 ppm; T8, nano-boron at 20 ppm + nano-zinc at 200 ppm 
Table 4 Effect of foliar application of $\mathrm{B}_{2} \mathrm{O}_{3}$ and $\mathrm{ZnO}$ nanoparticles on leaf minerals content of Picual cultivar in 2017 and 2018 seasons

\begin{tabular}{|c|c|c|c|c|c|c|c|c|c|c|c|c|}
\hline \multirow[t]{2}{*}{ Treat. } & \multicolumn{2}{|l|}{ N (\%) } & \multicolumn{2}{|l|}{ P (\%) } & \multicolumn{2}{|l|}{ K (\%) } & \multicolumn{2}{|c|}{$\mathrm{Fe}(\mathrm{ppm})$} & \multicolumn{2}{|c|}{ Zn (ppm) } & \multicolumn{2}{|l|}{ B (ppm) } \\
\hline & 2017 & 2018 & 2017 & 2018 & 2017 & 2018 & 2017 & 2018 & 2017 & 2018 & 2017 & 2018 \\
\hline TO & $1.72 \mathrm{e}$ & $1.53 \mathrm{e}$ & $0.214 c$ & $0.219 a b c$ & $1.21 \mathrm{~d}$ & $1.27 \mathrm{~d}$ & $297.0 \mathrm{~b}$ & $203.7 \mathrm{~g}$ & $26.40 \mathrm{~g}$ & $30.26 \mathrm{~cd}$ & $28.31 \mathrm{~b}$ & $35.18 c$ \\
\hline $\mathrm{T} 1$ & $1.72 \mathrm{e}$ & $1.66 \mathrm{c}$ & $0.215 c$ & $0.224 a b$ & $1.50 \mathrm{c}$ & $1.33 \mathrm{abcd}$ & $297.1 \mathrm{~b}$ & $224.1 \mathrm{e}$ & $27.23 \mathrm{f}$ & 29.83 de & $28.63 \mathrm{~b}$ & $35.26 c$ \\
\hline $\mathrm{T} 2$ & $1.84 \mathrm{C}$ & $1.63 \mathrm{~cd}$ & $0.216 c$ & $0.225 a b$ & $1.55 b c$ & $1.40 \mathrm{a}$ & $265.3 \mathrm{~d}$ & $199.3 \mathrm{~h}$ & $28.40 \mathrm{e}$ & $30.93 c$ & 28.97 b & $38.50 \mathrm{a}$ \\
\hline T3 & $1.88 \mathrm{~b}$ & $1.60 \mathrm{~d}$ & $0.214 c$ & $0.203 c$ & $1.60 \mathrm{ab}$ & $1.37 \mathrm{abc}$ & $230.6 f$ & $197.1 \mathrm{i}$ & $29.16 d$ & $30.80 \mathrm{c}$ & $25.03 \mathrm{~cd}$ & $28.57 \mathrm{f}$ \\
\hline T4 & $1.86 b c$ & $1.61 \mathrm{~d}$ & $0.218 c$ & $0.209 b c$ & $1.62 \mathrm{ab}$ & $1.32 \mathrm{bcd}$ & 249.7 e & 286.2 c & $30.83 \mathrm{~b}$ & $33.30 \mathrm{ab}$ & $25.25 c$ & $35.11 \mathrm{c}$ \\
\hline T5 & $1.91 \mathrm{a}$ & $2.06 \mathrm{a}$ & $0.231 \mathrm{a}$ & $0.204 \mathrm{c}$ & $1.56 \mathrm{bc}$ & $1.28 \mathrm{~d}$ & $305.1 \mathrm{a}$ & 297.6 a & $28.33 \mathrm{e}$ & $30.23 \mathrm{~cd}$ & $21.23 \mathrm{e}$ & $32.97 \mathrm{~d}$ \\
\hline T6 & $1.72 \mathrm{e}$ & $2.04 a$ & $0.235 \mathrm{a}$ & $0.231 \mathrm{a}$ & $1.56 b c$ & $1.30 \mathrm{~cd}$ & $269.0 \mathrm{c}$ & $212.8 f$ & $28.06 \mathrm{e}$ & $29.20 \mathrm{e}$ & $30.35 \mathrm{a}$ & $33.07 \mathrm{~d}$ \\
\hline T7 & $1.75 \mathrm{~d}$ & 1.74 b & $0.224 b$ & $0.231 \mathrm{a}$ & $1.57 \mathrm{abc}$ & $1.38 \mathrm{ab}$ & $223.7 \mathrm{~g}$ & $231.6 \mathrm{~d}$ & $32.00 \mathrm{a}$ & 34.09 a & $24.4 \mathrm{~d}$ & $31.65 \mathrm{e}$ \\
\hline T8 & $1.84 \mathrm{C}$ & $1.77 \mathrm{~b}$ & $0.232 \mathrm{a}$ & $0.234 \mathrm{a}$ & $1.64 \mathrm{a}$ & $1.39 \mathrm{ab}$ & $298.0 \mathrm{~b}$ & 294.4 b & $30.16 c$ & $32.86 \mathrm{~b}$ & $31.08 \mathrm{a}$ & $37.50 \mathrm{~b}$ \\
\hline
\end{tabular}

Mean in each column with similar letters is not significantly different at $5 \%$ level

T1, nano-boron at 10 ppm; T2, nano-boron at 20 ppm; T3, nano-zinc at 100 ppm; T4, nano-zinc at 200 ppm; T5, nano-boron at 10 ppm + nano-zinc at 100 ppm; T6, nano-boron at $10 \mathrm{ppm}+$ nano-zinc at 200 ppm; T7, nano-boron at 20 ppm + nano-zinc at 100 ppm; T8, nano-boron at 20 ppm + nano-zinc at 200 ppm

(1.72 and $1.53 \%)$ in the first and second seasons, respectively. Moreover, insignificant differences were detected between $\mathrm{T} 0$ and $\mathrm{T} 1$ in the first season and between $\mathrm{T} 5$ and T6 in the second one, respectively.

Concerning phosphorus percentage in leaves, the results in Table 4 cleared that trees spraying with nano-boron at $10 \mathrm{ppm}+$ nano-zinc at $200 \mathrm{ppm}$ (T6) and nano-boron at $20 \mathrm{ppm}+$ nano-zinc at $200 \mathrm{ppm}$ (T8) exhibited the maximum of phosphorus percentages in leaves $(0.235$ and $0.234 \%$ for $\mathrm{T} 6$ and $\mathrm{T} 8$, respectively) in both studied seasons, respectively. Meanwhile, the control sprayed trees with nano-zinc at $100 \mathrm{ppm}$ (T3) recorded the lowest percentages in this regard $(0.214$ and $0.214 \%$, for T0 and T3, respectively) in the first season. On the other hand, the application with nano-zinc at $100 \mathrm{ppm}$ only (T3) recorded the lowest value since it was $(0.203 \%)$ in the second season. Moreover, in the first season, insignificant differences were found between cont, T1, T2, T3, and T4 and also between T5 and T6. While in the second season, the same situation was found with cont, T3 and T5 and between T0, T1, T2, T6, T7, and $\mathrm{T} 8$, respectively.

It is clear from the results in Table 4 that different treatments affected in leaf percentage of potassium in both seasons. Spraying with nano-boron at $20 \mathrm{ppm}+$ nano-zinc at $200 \mathrm{ppm}$ (T8) and spraying with nano-boron at $20 \mathrm{ppm}$ (T2) produced the highest percentages of $\mathrm{K}$ in leaves (1.64 and $1.40 \%)$ in the first and second seasons, respectively. However, the control treatment recorded the lowest values in this respect (1.21 and 1.27\%) in the first and second seasons, severally. Other treatments were intermediate in this respect. Insignificant differences were recorded between $\mathrm{T} 3, \mathrm{~T} 4, \mathrm{~T} 7$, and $\mathrm{T} 8$ in the first season and between $\mathrm{T} 2, \mathrm{~T} 7$, and $\mathrm{T} 8$ as well as between cont, $\mathrm{T} 1, \mathrm{~T} 4, \mathrm{~T} 5$, and $\mathrm{T} 6$ in the second season.

It is clear from the results in Table 4 reviled that all different spraying treatments significantly affected leaf Fe during both seasons. Trees treated with nano-boron at $10 \mathrm{ppm}+$ nano-zinc at $100 \mathrm{ppm}$ (T5) gave the maximum values in this respect (305.1 and $297.6 \mathrm{ppm}$ ) in the first and second seasons, respectively, compared with the other treatments and control trees. Otherwise, spraying with nano-boron at $20 \mathrm{ppm}+$ nano-zinc at $100 \mathrm{ppm}$ (T7) exhibited the minimum leaves iron $(223.7 \mathrm{ppm})$ in the first season. Meanwhile, spraying by nano-zinc at $100 \mathrm{ppm}$ (T3) gave the lowest value (197.1 ppm) in the second one. Other treatments were in between range in this regard.

Data presented in Table 4 indicated that leaves zinc content was affected by conducted treatments. As for tree spraying with nano-boron at $20 \mathrm{ppm}+$ nano-zinc at $100 \mathrm{ppm}$ (T7) recorded the highest values in this regard since there were ( 32.00 and $34.09 \mathrm{ppm})$ in both studied seasons, respectively. On the other hand, the lowest values were observed with treatments of control and nano-boron at $10 \mathrm{ppm}+$ nano-zinc at $200 \mathrm{ppm}$ (T6) since there were $(26.40$ and $29.20 \mathrm{ppm})$ in both studied seasons, respectively, other treatments in between the range.

The results in Table 4 showed that most treatments led to different significant influence on leaves boron content in both seasons. Spraying with nano-boron at $20 \mathrm{ppm}+$ nano-zinc at $200 \mathrm{ppm}$ (T8) and nano-boron at $10 \mathrm{ppm}+$ nano-zinc at $200 \mathrm{ppm}$ (T6) produced the highest significant values ( 31.08 and $30.35 \mathrm{ppm})$ in the first season, whereas foliar application by nano-boron at 20 ppm (T2) obtained the maximum of leaf boron (38.50 $\mathrm{ppm})$ in the second season as compared with other treatments. On the other side, the minimum content of 
leaves boron was found with trees sprayed by nanoboron at $10 \mathrm{ppm}+$ nano-zinc at $100 \mathrm{ppm}$ (T5) in this respect $(21.23 \mathrm{ppm})$ in the first season and with nano-zinc at $100 \mathrm{ppm}$ (T3) since it was $(28.57 \mathrm{ppm})$ in the second season.

\section{Fruit set, fruit drop, and yield}

Data presented in Table 5 revealed that final fruit set percentage was affected by conducted treatments. Tree spray with nano-boron at $20 \mathrm{ppm}+$ nano-zinc at 200 ppm (T8) and nano-boron at $20 \mathrm{ppm}+$ nano-zinc at $100 \mathrm{ppm}$ (T7) cleared the maximum values (31.41 and $30.96 \%$ ), respectively, in the first season. However, trees spray with nano-boron at $20 \mathrm{ppm}+$ nano-zinc at 200 ppm (T8) recorded the highest fruit set percentage; it was $23.91 \%$ in the second season. On the other side, the lowest values were recorded with the treatment of nanoboron at $10 \mathrm{ppm}+$ nano-zinc at $100 \mathrm{ppm}$ (T5) and the control treatment $(21.57$ and $15.90 \%)$ in both studied seasons, respectively. Other treatments were in between the range. Also, insignificant differences were detected between the treatments from $\mathrm{T} 1$ to $\mathrm{T} 5$ in the first season.

Concerning fruit drop percentage, the results in Table 5 showed that the fruit drop percentage was affected by most concentrations treatments. Treated trees with nano-boron at $10 \mathrm{ppm}+$ nano-zinc at $200 \mathrm{ppm}$ (T6) had the minimum fruit drop (19.85\%) in the first season, but spraying with nano-boron at $20 \mathrm{ppm}+$ nano-zinc at 200 ppm (T8) gave the lowest fruit drop percentage (21.85\%) in the second season. On the other hand, trees received nano-zinc at $200 \mathrm{ppm}$ (T4), and the control treatment

Table 5 Effect of foliar application of $\mathrm{B}_{2} \mathrm{O}_{3}$ and $\mathrm{ZnO}$ nanoparticles on fruit yield traits of Picual cultivar in 2017 and 2018 seasons

\begin{tabular}{|c|c|c|c|c|c|c|}
\hline \multirow[t]{2}{*}{ Treat. } & \multicolumn{2}{|c|}{ Final fruit set (\%) } & \multicolumn{2}{|c|}{ Fruit drop (\%) } & \multicolumn{2}{|c|}{ Yield (kg/tree) } \\
\hline & 2017 & 2018 & 2017 & 2018 & 2017 & 2018 \\
\hline ont. & $23.88 c$ & $15.90 \mathrm{~g}$ & $20.65 c$ & $30.02 \mathrm{a}$ & 25.67 bcde & $17.10 \mathrm{f}$ \\
\hline T1 & $23.59 \mathrm{~cd}$ & $17.49 f$ & $33.09 \mathrm{a}$ & $25.05 \mathrm{bc}$ & $22.33 \mathrm{e}$ & $17.20 \mathrm{f}$ \\
\hline $\mathrm{T} 2$ & $21.95 \mathrm{~cd}$ & 18.53 de & $36.39 a$ & $24.37 b c$ & 24.00 cde & $17.63 f$ \\
\hline T3 & $22.93 \mathrm{~cd}$ & 17.60 ef & $34.56 \mathrm{a}$ & $26.73 a b$ & $27.33 a b c$ & 19.23 e \\
\hline T4 & $22.54 \mathrm{~cd}$ & 18.50 de & $37.00 \mathrm{a}$ & $26.38 \mathrm{abc}$ & $28.67 a b$ & $20.33 d$ \\
\hline T5 & $21.57 \mathrm{~d}$ & $18.73 d$ & $26.71 \mathrm{~b}$ & $26.54 a b$ & $26.67 \mathrm{abcd}$ & $20.50 d$ \\
\hline T6 & $25.89 \mathrm{~b}$ & $21.97 b$ & $19.85 \mathrm{C}$ & $24.06 \mathrm{bc}$ & 23.33 de & $23.00 \mathrm{~b}$ \\
\hline T7 & 30.96 a & $20.75 c$ & $33.84 \mathrm{a}$ & $21.97 c$ & $26.33 \mathrm{abcd}$ & $22.13 c$ \\
\hline T8 & $31.41 \mathrm{a}$ & $23.91 \mathrm{a}$ & $33.07 \mathrm{a}$ & $21.85 \mathrm{C}$ & 29.33 a & $23.87 \mathrm{a}$ \\
\hline
\end{tabular}

Mean in each column with similar letters is not significantly different at $5 \%$ level

$\mathrm{T} 1$, nano-boron at $10 \mathrm{ppm} ; \mathrm{T} 2$, nano-boron at $20 \mathrm{ppm}$; T3, nano-zinc at 100 ppm; T4, nano-zinc at 200 ppm; T5, nano-boron at 10 ppm + nano-zinc at 100 ppm; T6, nano-boron at $10 \mathrm{ppm}$ + nano-zinc at $200 \mathrm{ppm}$; T7, nano-boron at $20 \mathrm{ppm}+$ nano-zinc at $100 \mathrm{ppm} ; \mathrm{T} 8$, nano-boron at $20 \mathrm{ppm}+$ nano-zinc at $200 \mathrm{ppm}$ presented the maximum fruit drop percentages since it was (37.00 and 30.02\%) in the first and second seasons, respectively. On the other side, other treatments were intermediate in this respect. Insignificant differences were found between T1, T2, T3, T4, T7, and T8 as well as between $\mathrm{T} 0$ and $\mathrm{T} 6$ in the first season and between T0, T3, T4, and T5 and also between T1, T2, T4, T6, $\mathrm{T} 7$, and $\mathrm{T} 8$ in the second season.

Regard to yield, the results in Table 5 revealed that the most treatments significantly increased yield as $(\mathrm{kg})$ per tree than the control in both seasons. In this manner, spraying trees with nano-boron at $20 \mathrm{ppm}+$ nano-zinc at $200 \mathrm{ppm}$ (T8) produced the highest yield per tree ( 29.33 and $23.87 \mathrm{~kg} /$ tree) in the first and second seasons, respectively. On the other side, spraying with nanoboron at $10 \mathrm{ppm}$ (T1) and the control trees exhibited the minimum of yield values in this regard (22.33 and 17.10 $\mathrm{kg} /$ tree) in both studied seasons, respectively. In the first season, insignificant differences were recorded between $\mathrm{T} 3, \mathrm{~T} 4, \mathrm{~T} 5, \mathrm{~T} 7$, and $\mathrm{T} 8$ and between $\mathrm{T} 0, \mathrm{~T} 1, \mathrm{~T} 2$, and $\mathrm{T} 6$ while in the second season the same situation was noticed with T0, T1, and T2.

\section{Fruit physical properties}

Data cleared in Table 6 indicated that fruit weight was significantly affected by spraying nano-boron and zinc in the two studied seasons. Tree spraying with nano-boron at $20 \mathrm{ppm}+$ nano-zinc at $100 \mathrm{ppm}$ (T7) recorded the largest fruit weight $(6.90 \mathrm{~g})$ in the first season with insignificant differences between T4, T6, T7, and T8, respectively. Furthermore, in the second season, data clear that spraying with nano-boron at $20 \mathrm{ppm}+$ nanozinc at $200 \mathrm{ppm}$ (T8) gave the largest significant value $(6.83 \mathrm{~g})$ in this respect. In addition, untreated trees (control) obtained the minimum significant values of fruit weight (4.94 and $5.64 \mathrm{~g}$ ) during the first and second seasons, respectively.

The results presented in Table 6 showed that all different treatments increase pulp weight as compared with control treatment. As for tree spray with nano-boron at $20 \mathrm{ppm}+$ nano-zinc at $100 \mathrm{ppm}$ (T7) and tree spray with nano-boron at $20 \mathrm{ppm}+$ nano-zinc at $200 \mathrm{ppm}$ (T8) recorded the highest values in this respect, since there were 5.90 and $5.88 \mathrm{~g}$ in both studied seasons, respectively, with insignificant differences between T4, T6, T7, and T8, in the first season only. Meanwhile, the lowest values of pulp weight were under control treatment ( 4.07 and $4.80 \mathrm{~g}$ ) in this regard during the first and second seasons, respectively.

Also, data in Table 6 reported that most treatments affected in pulp: seed ratio than the control in the first and second seasons. In this manner, spraying trees with nano-boron at $20 \mathrm{ppm}+$ nano-zinc at $200 \mathrm{ppm}$ (T8) produced the maximum ratio (7.25) in this respect during 
Table 6 Effect of foliar application of $\mathrm{B}_{2} \mathrm{O}_{3}$ and $\mathrm{ZnO}$ nanoparticles on fruit traits of Picual cultivar in 2017 and 2018 seasons

\begin{tabular}{|c|c|c|c|c|c|c|c|c|c|c|}
\hline \multirow[t]{2}{*}{ Treat. } & \multicolumn{2}{|c|}{ Fruit weight (g) } & \multicolumn{2}{|c|}{ Pulp weight (g) } & \multicolumn{2}{|c|}{ Pulp/seed ratio } & \multicolumn{2}{|c|}{ Fruit length $(\mathrm{cm})$} & \multicolumn{2}{|c|}{ Fruit diameter $(\mathrm{cm})$} \\
\hline & 2017 & 2018 & 2017 & 2018 & 2017 & 2018 & 2017 & 2018 & 2017 & 2018 \\
\hline TO & $4.94 \mathrm{~d}$ & $5.64 \mathrm{~h}$ & $4.07 c$ & $4.80 \mathrm{~g}$ & $4.73 \mathrm{e}$ & $5.71 \mathrm{C}$ & $2.46 \mathrm{~d}$ & $2.44 \mathrm{~g}$ & $1.98 \mathrm{~d}$ & $1.98 \mathrm{e}$ \\
\hline $\mathrm{T} 1$ & $6.10 b c$ & $5.99 \mathrm{fg}$ & $5.00 \mathrm{~b}$ & $5.13 f$ & $4.55 \mathrm{e}$ & $5.99 \mathrm{~b}$ & $2.58 b c$ & $2.60 \mathrm{f}$ & $2.09 \mathrm{bc}$ & $2.10 \mathrm{c}$ \\
\hline $\mathrm{T} 2$ & $5.81 \mathrm{C}$ & $6.27 \mathrm{e}$ & $4.89 \mathrm{~b}$ & $5.40 \mathrm{e}$ & 5.30 de & $6.21 \mathrm{a}$ & $2.68 \mathrm{ab}$ & $2.66 \mathrm{e}$ & $2.08 b c$ & $2.11 \mathrm{c}$ \\
\hline T3 & $5.65 c$ & $5.98 \mathrm{~g}$ & $4.88 \mathrm{~b}$ & $5.15 f$ & $6.39 \mathrm{abc}$ & $6.20 \mathrm{a}$ & $2.56 \mathrm{c}$ & $2.72 \mathrm{c}$ & $2.08 b c$ & $2.02 \mathrm{c}$ \\
\hline T4 & $6.55 a b$ & $6.40 \mathrm{~d}$ & $5.72 \mathrm{a}$ & $5.49 \mathrm{~d}$ & $6.97 \mathrm{ab}$ & $6.03 b$ & $2.65 a b c$ & $2.78 \mathrm{~b}$ & $2.12 a b$ & $2.10 \mathrm{c}$ \\
\hline T5 & $5.91 \mathrm{C}$ & $6.04 \mathrm{f}$ & $5.10 \mathrm{~b}$ & $5.15 f$ & $6.36 a b c$ & $5.81 \mathrm{C}$ & $2.65 a b c$ & $2.68 \mathrm{~d}$ & $2.03 \mathrm{~cd}$ & $2.09 c$ \\
\hline T6 & $6.85 \mathrm{a}$ & $6.48 c$ & $5.88 \mathrm{a}$ & $5.57 c$ & $6.08 \mathrm{bcd}$ & $6.09 a b$ & $2.73 a$ & $2.79 \mathrm{~b}$ & $2.16 a b$ & $2.13 b$ \\
\hline T7 & $6.90 \mathrm{a}$ & $6.70 \mathrm{~b}$ & $5.90 \mathrm{a}$ & $5.77 \mathrm{~b}$ & $5.89 \mathrm{~cd}$ & $6.20 \mathrm{a}$ & $2.72 \mathrm{a}$ & $2.79 b$ & $2.18 \mathrm{a}$ & $2.13 b$ \\
\hline T8 & $6.60 \mathrm{ab}$ & $6.83 a$ & $5.80 \mathrm{a}$ & $5.88 \mathrm{a}$ & $7.25 \mathrm{a}$ & $6.19 a$ & $2.68 \mathrm{ab}$ & $2.86 \mathrm{a}$ & $2.15 a b$ & $2.16 \mathrm{a}$ \\
\hline
\end{tabular}

Mean in each column with similar letters is not significantly different at $5 \%$ level

$\mathrm{T} 1$, nano-boron at 10 ppm; T2, nano-boron at 20 ppm; T3, nano-zinc at 100 ppm; T4, nano-zinc at 200 ppm; T5, nano-boron at 10 ppm + nano-zinc at 100 ppm; T6, nano-boron at 10 ppm + nano-zinc at 200 ppm; T7, nano-boron at 20 ppm + nano-zinc at 100 ppm; T8, nano-boron at 20 ppm + nano-zinc at 200 ppm

the first season, while spraying trees with nano-boron at $20 \mathrm{ppm}$ (T2) showed the highest value (6.21) in the second season. On the other hand, treated with nano-boron at $20 \mathrm{ppm}$ (T1) recorded the least ratio (4.55) in the first season; furthermore, the control treatment had the minimum pulp: seed ratio (5.71) in the second one. Insignificant differences were recorded in the first season between $\mathrm{T} 3, \mathrm{~T} 4, \mathrm{~T} 5$, and $\mathrm{T} 8$ and between $\mathrm{T} 0, \mathrm{~T} 1$, and $\mathrm{T} 2$ as well as in the second season between T2, T3, T6, $\mathrm{T} 7$, and $\mathrm{T} 8$ and also between cont and $\mathrm{T} 5$, respectively.

Data in Table 6 indicated that fruit length was significantly affected by different treatments as compared with control in both studied seasons, respectively. In the first season, application with nano-boron at $10 \mathrm{ppm}+$ nanozinc at $200 \mathrm{ppm}$ (T6) gave the maximum fruit length since it was $(2.73 \mathrm{~cm})$ with insignificant differences between T2, T4, T5, T6, T7, and T8. Spraying with nanoboron at $20 \mathrm{ppm}+$ nano-zinc at $200 \mathrm{ppm}$ (T8) recorded the maximum significant value $(2.86 \mathrm{~cm})$ in the second season, while the lowest significant values were shown with the control treatment in this respect (2.46 and 2.44 $\mathrm{cm}$ ) in both studied seasons, respectively.

It is clear from the results in Table 6 that all different spraying treatments significantly increased fruit diameter than the control during both seasons except $\mathrm{T} 5$ which recorded insignificant differences between it and the control in the first season. Trees sprayed with nanoboron at $20 \mathrm{ppm}+$ nano-zinc at $100 \mathrm{ppm}$ (T7) gave the largest value $(2.18 \mathrm{~cm})$ in the first season. Otherwise, in the second season spraying by nano-boron at $20 \mathrm{ppm}+$ nano-zinc at $200 \mathrm{ppm}$ (T8) recorded the highest significant fruit diameter $(2.16 \mathrm{~cm})$ compared with other treatments. On the other side, the control treatment exhibited the minimum of fruit diameter values, since there were 1.98 and $198 \mathrm{~cm}$ in the first and second season, respectively. Other treatments were in between the range.

\section{Fruit oil percentage}

Data in Table 7 showed that all different spraying treatments significantly increased fruit oil percentage on dry weight basis than the control during both seasons. Trees sprayed with nano-boron at $20 \mathrm{ppm}+$ nano-zinc at 200 ppm (T8) gave the maximum significant fruit oil percentage $(40.71 \%)$ in the first season. Moreover, the trees treated with nano-boron at $10 \mathrm{ppm}+$ nano-zinc at 200 ppm (T6) recorded the highest significant value (43.20\%) in this respect in the second season. On the other side, the control trees exhibited the minimum significant fruit oil percentages (33.33 and 35.30\%) in both seasons, respectively. Meanwhile, the other treatments were in between range.

\section{Oil chemical properties}

Concerning oil acidity results in Table 7 revealed that oil acidity was significantly affected by different concentration treatments; it ranged from 0.15 to $0.37 \%$ in the first season, while in the second one it ranged between 0.16 and $0.38 \%$. However, the lowest oil acidity percentages were found with trees spraying with nano-boron at 20 $\mathrm{ppm}+$ nano-zinc at $200 \mathrm{ppm}$ (T8) (0.15\%) in the first season. While the treatments of nano-boron at $20 \mathrm{ppm}$ + nano-zinc at $200 \mathrm{ppm}$ (T8) and nano-boron at $20 \mathrm{ppm}$ (T2) recorded the minimum oil acidity percentage $(0.16$ and $0.16 \%)$ in the second season, respectively. Meanwhile, the highest significant oil acidity percentages were recorded with the control trees $(0.37$ and $0.38 \%)$ in the first and second seasons, respectively.

Regarding iodine value, in Table 7 showed that peroxide value was significantly affected by different concentration treatments in both seasons. However, peroxide values ranged from 3.59 to $5.12 \mathrm{meq} / \mathrm{kg}$ and from 3.58 to $5.18 \mathrm{meq} / \mathrm{kg}$ in the first and second seasons, respectively. Also, the lowest peroxide values (3.59 and 3.58 $\mathrm{meq} / \mathrm{kg}$ ) were obtained with trees sprayed with nano- 
Table 7 Effect of foliar application of $\mathrm{B}_{2} \mathrm{O}_{3}$ and $\mathrm{ZnO}$ nanoparticles on fruit oil traits of Picual cultivar in 2017 and 2018 seasons

\begin{tabular}{|c|c|c|c|c|c|c|c|c|}
\hline \multirow[t]{2}{*}{ Treat. } & \multicolumn{2}{|c|}{ Fruit oil percentage (\%) } & \multicolumn{2}{|c|}{ Oil acidity (\%) } & \multicolumn{2}{|c|}{ Peroxide value (meq/kg oil) } & \multicolumn{2}{|c|}{ lodine value (g/100 g oil) } \\
\hline & 2017 & 2018 & 2017 & 2018 & 2017 & 2018 & 2017 & 2018 \\
\hline TO & $33.33 \mathrm{i}$ & $35.30 \mathrm{~g}$ & $0.37 \mathrm{a}$ & $0.38 \mathrm{a}$ & $5.04 b$ & $5.09 \mathrm{~b}$ & $81.14 \mathrm{~h}$ & $78.57 \mathrm{i}$ \\
\hline T1 & $39.07 \mathrm{~g}$ & $37.07 \mathrm{f}$ & $0.27 b$ & $0.25 \mathrm{~b}$ & $3.96 \mathrm{e}$ & $4.00 \mathrm{~d}$ & $81.06 \mathrm{i}$ & $84.52 \mathrm{C}$ \\
\hline $\mathrm{T} 2$ & $39.72 \mathrm{~d}$ & $39.14 \mathrm{e}$ & $0.17 \mathrm{e}$ & $0.16 d$ & $3.59 \mathrm{i}$ & $3.58 \mathrm{~g}$ & $84.43 \mathrm{f}$ & $85.44 \mathrm{a}$ \\
\hline T3 & $38.23 \mathrm{~h}$ & $40.90 \mathrm{~d}$ & $0.25 \mathrm{c}$ & $0.26 \mathrm{~b}$ & $3.89 \mathrm{f}$ & $3.87 \mathrm{e}$ & 86.95 b & $82.09 \mathrm{~h}$ \\
\hline $\mathrm{T} 4$ & $39.43 \mathrm{e}$ & $42.42 b$ & $0.27 b$ & $0.26 b$ & $5.12 \mathrm{a}$ & $5.18 \mathrm{a}$ & $88.80 \mathrm{a}$ & $82.36 \mathrm{~g}$ \\
\hline T5 & $39.83 c$ & $41.02 \mathrm{c}$ & $0.27 b$ & $0.25 \mathrm{~b}$ & $4.78 \mathrm{c}$ & $5.16 \mathrm{a}$ & 84.61 e & $83.14 \mathrm{f}$ \\
\hline T6 & $40.19 \mathrm{~b}$ & $43.20 \mathrm{a}$ & $0.25 c$ & $0.23 c$ & $3.62 \mathrm{~h}$ & $3.66 f$ & $82.44 \mathrm{~g}$ & $83.91 \mathrm{e}$ \\
\hline T7 & $39.10 \mathrm{f}$ & $42.41 \mathrm{~b}$ & $0.21 \mathrm{~d}$ & $0.22 \mathrm{c}$ & $3.83 \mathrm{~g}$ & $3.82 \mathrm{e}$ & $85.03 \mathrm{~d}$ & $85.20 \mathrm{~b}$ \\
\hline T8 & $40.71 \mathrm{a}$ & $42.49 \mathrm{~b}$ & $0.15 \mathrm{e}$ & $0.16 d$ & $4.42 d$ & $4.49 \mathrm{C}$ & $85.64 \mathrm{C}$ & $84.24 d$ \\
\hline
\end{tabular}

Mean in each column with similar letters is not significantly different at $5 \%$ level

T1, nano-boron at 10 ppm; T2, nano-boron at 20 ppm; T3, nano-zinc at 100 ppm; T4, nano-zinc at 200 ppm; T5, nano-boron at 10 ppm + nano-zinc at 100 ppm; T6, nano-boron at 10 ppm + nano-zinc at 200 ppm; T7, nano-boron at 20 ppm + nano-zinc at 100 ppm; T8, nano-boron at 20 ppm + nano-zinc at 200 ppm

boron at $20 \mathrm{ppm}$ (T2) in the two studied seasons. Meanwhile, trees sprayed with nano-zinc at $200 \mathrm{ppm}(\mathrm{T} 4)$ exhibited the maximum significant value in this respect $(5.12 \mathrm{meq} / \mathrm{kg})$ in the first season. Moreover, in the second season, spraying with nano-zinc at $200 \mathrm{ppm}$ (T4) followed with nano-boron at $10 \mathrm{ppm}+$ nano-zinc at 100 ppm (T5) presented the largest significant values (5.18 and $5.16 \mathrm{meq} / \mathrm{kg}$ ) in this respect, respectively. Other treatments were intermediate.

Concerning iodine value, in Table 7 results showed that spraying different treatments led to affected in iodine value in both seasons; it range from 81.06 to $88.80 \mathrm{~g} / 100 \mathrm{~g}$ oil in the first season, while in the second one it ranged between 78.57 and $85.44 \mathrm{~g} / 100 \mathrm{~g}$ oil. Spraying nano-zinc at $200 \mathrm{ppm}$ only (T4) and nano-boron at $20 \mathrm{ppm}$ only (T2) produced the maximum significant iodine values $(88.80$ and $85.44 \mathrm{mg} /$ $\mathrm{kg}$ ) in the first and second seasons, respectively. However, spraying with nano-boron at $10 \mathrm{ppm}$ (T1) gave the significant least value $(81.06 \mathrm{mg} / \mathrm{kg})$ in this respect in the first season, but in the second one the control treatment recorded the significant lowest value (78.57 $\mathrm{mg} / \mathrm{kg}$ ) in this respect compared with the other treatments. Other treatments were in between range.

\section{Discussion}

The improving in chlorophyll a and $\mathrm{b}$ content as a result of using nano-boron and nano-zinc similar to results that were obtained by Keshavarz et al. (2011); they showed that spraying zinc sulfate at $1050 \mathrm{ppm}+$ boric acid at $174 \mathrm{ppm}$ gave the highest leaf chlorophyll index of walnut trees. Additionally, Mahmoud (2014) reported that spraying by nano-boron at $0.1 \%$ at four times gave the highest leaf chlorophyll $\mathrm{a}$ and $\mathrm{b}$ contents and total carotenoids of Zaghloul date palms leaves. Moreover, ElMetwally et al. (2018) indicated that soil application by mixer of nano-fertilizers (nano- $\mathrm{Zn}+$ nano-Fe + nano-
$\mathrm{Mn})$ at $0.03 \mathrm{~g} / \mathrm{l}$ on peanuts plants gave the highest values of total chlorophyll and carotenoids in peanut leaves.

All used treatments were able to increase leaf mineral contents in this study These observations are in accordance with those obtained by Keshavarz et al. (2011) who showed that spraying with zinc sulfate at $1750 \mathrm{ppm}+$ boric acid at $348 \mathrm{ppm}$ gave the highest leaves nutrient concentrations as $\mathrm{K}, \mathrm{Zn}, \mathrm{B}$, and $\mathrm{Zn}$ of walnut trees. The same other, Mahmoud (2014) reported that spraying with $0.1 \%$ nano-boron at four times gave the highest leaves $\mathrm{N}, \mathrm{P}$, and $\mathrm{K}$ contents of Zaghloul date palms leaves. In the same respect, on olive trees, Saadati et al. (2016) showed that foliar spraying with $2.5 \mathrm{~g} / \mathrm{l}$ boric acid $+2.5 \mathrm{~g} / \mathrm{l}$ zinc sulfate at full bloom and 15 days later increased leaves zinc content. While spraying with boric acid at $2.5 \mathrm{~g} / \mathrm{l}$ alone or combination with zinc sulfate at $2.5 \mathrm{~g} / \mathrm{l}$ increased leaves boron content compared with the control. As well as, on pomegranate trees, Davarpanah et al. (2016) showed that application by nano- $\mathrm{Zn}$ at $120 \mathrm{ppm}+$ nano-B at $3.25 \mathrm{ppm}$ increased the leaves concentrations of $\mathrm{N}, \mathrm{K}$, and $\mathrm{Zn}$. Also, spraying by nano-B at $6.5 \mathrm{ppm}$ gave the highest concentration of $\mathrm{B}$ in leaves. Also, on Gemlik olive trees, Basar and Gürel (2016) reported that every treatments of $\mathrm{Zn}$ increased $\mathrm{Zn}$ content of leaves and $\mathrm{Zn}$ content of fruits; also, foliar applications with $\mathrm{Zn}, \mathrm{B}$, and Fe gave the highest $\mathrm{Zn}, \mathrm{B}$, and Fe concentrations in the olive leaves and fruits. Moreover, El-Metwally et al. (2018) indicated that soil application by mixer of nano-fertilizers (nano-Zn + nano-Fe + nano- $\mathrm{Mn}$ ) at $0.03 \mathrm{~g} / \mathrm{l}$ on peanuts plants gave the highest values of $\mathrm{N}, \mathrm{P}, \mathrm{Zn}$, and $\mathrm{Fe}$ and contents in the straw of peanuts.

Most used treatments were able to improve fruit set, fruit drop, and yield of olive tree The present's results are in agreement with those found by Mahmoud (2014) who illustrated that spraying with nano-boron at $0.1 \%$ at four times gave the highest yield $(\mathrm{kg} / \mathrm{palm})$ of Zaghloul 
date palms compared with other treatments. In this manner, on olive trees, Sayyad-amin et al. (2015) showed that application with zinc sulfate at $2000 \mathrm{ppm}$ alone or boric acid at $2000 \mathrm{ppm}$ plus zinc sulfate at $2000 \mathrm{ppm}$ or plus urea at 5000 gave the highest initial and final fruit set percentage and yield ( $\mathrm{kg} /$ tree) compared with other treatments. Besides, on olive trees, Saadati et al. (2016) noticed that spraying with boric acid enhanced the initial fruit set percentage while spraying with boric acid + zinc sulfate increased the final fruit set percentage of trees. Also, on pomegranate trees, Davarpanah et al. (2016) found that foliar spraying with nano-Zn at $60 \mathrm{ppm}+$ nano-B at $6.5 \mathrm{ppm}$ gave the highest number of fruits per tree and yield $(\mathrm{kg} /$ tree) as compared with other treatments. Additionally, on Kagzi lime trees, Venu and Delvadia (2018) mentioned that foliar spraying with $0.5 \%$ $\mathrm{ZnSO}_{4}+0.4 \%$ borax gave the highest fruit set percentage, number fruits per shoot, number of fruits per tree, fruit yield ( $\mathrm{kg} /$ tree), and yield ( $\mathrm{kg} / \mathrm{ha})$ and gave the minimum fruit drop percentage compared with untreated trees. While on pomegranate trees, Dhurve et al. (2018) showed that foliar application with $0.4 \%$ boric acid + $0.4 \%$ zinc sulfate gave the highest number of fruit per shoot and yield ( $\mathrm{kg} /$ tree).

The improvement in fruit physical properties with spraying nano-boron and nano-zinc in accordance with those found by Mahmoud (2014) who clearly showed that spraying with nano-boron at $0.1 \%$ in four times improved fruit weight, length and width, pulp percentage, and pulp/seed ratio. Also, it gave the lowest seed percentage in Zaghloul date palms fruits. Moreover, on pomegranate trees, Davarpanah et al. (2016) reported that foliar spraying with nano-Zn at $120 \mathrm{ppm}+$ nano-B at $6.5 \mathrm{ppm}$ gave the highest fruit weight, length, and diameter. While on sweet orange trees, Singh et al. (2018) noticed that foliar spraying with $\mathrm{ZnSO}_{4}$ at $0.5 \%+$ $\mathrm{H}_{3} \mathrm{BO}_{3}$ at $0.7 \%$ gave the highest fruit physical properties as fruit weight, volume, length, and breadth of sweet orange cv. Mosambi. On the other hand, on olive trees Saadati et al. (2016) found that no significant differences between the treatments on fruit diameter, pit weight, length, and diameter, but spraying with zinc sulfate at $2.5 \mathrm{~g} / \mathrm{l}$ gave the highest fruit length.

The results of improving fruit oil percentage are in agreement with Saadati et al. (2013) who cleared that the treatment with zinc sulfate at $0.25 \%+$ boric acid at $0.25 \%$ increased fruit oil content from 11.7 to $19.4 \%$. In the same respect, on olive trees, Sayyad-amin et al. (2015) revealed that foliar application with boric acid at $2000 \mathrm{ppm}$ gave the highest fruit oil percentage compared with other treatments. Also, Abdel-Karim et al. (2015) indicated that foliar spraying with $1 \mathrm{~g} / \mathrm{l}$ zinc sulfate +1 $\mathrm{g} / \mathrm{l}$ borax gave the maximum of the fat percentage of fruit on Fuerte avocado trees.
The present's results improving oil chemical properties of olive fruits agree with those found by Saadati et al. (2013). They cleared that olive trees treated with zinc sulfate at $0.25 \%$ + boric acid at $0.25 \%$ had an increase in the ratio of unsaturated/saturated fatty acids compared to untreated plants; also, it gave the highest level of oleic acid and the lowest level of palmitic acid in oil of Coronaiki cv. fruit compared with other cultivars. Also, on pomegranate trees, Davarpanah et al. (2016) reported that foliar spraying with nano- $\mathrm{Zn}$ at $60 \mathrm{ppm}+$ nano-B at $6.5 \mathrm{ppm}$ gave the lowest total acidity percentage in fruit juice. In another word, on Washington navel orange trees, Hikal et al. (2017) reported that foliar application with $0.2 \%$ boric acid decreased fruit juice acidity compared to the control.

\section{Conclusion}

From the above-mentioned results, it could recommend that spraying Picual olive trees with nano-boron at 20 ppm + nano-zinc at $200 \mathrm{ppm}$ is the best treatment in this study to obtain the maximum final fruit set which led to harvest the maximum fruits yield with the high seed oil percentage and low acidity.

\section{Abbreviation}

RCBD: Randomized complete block design; ANOVA: Analysis of variances

\section{Acknowledgements}

This work did not have any funding support.

\section{Significance statement}

The study represented useful treatments to increase the quality and quantity of olive fruits and oil yields under the condition of salinity.

\section{Authors' contributions}

EAEG contributed to design and performance of the experiment and also data analysis, writing the manuscript, and following up the publication with the journal (correspondence). NAA contributed in the design and performance of the experiment and also data analysis and writing the manuscript. HSAH contributed in the design and performance of the experiment and also data analysis and writing the manuscript. AMH contributed in the design and performance of the experiment and also data analysis and writing the manuscript. LFH contributed in the design and performance of the experiment and also data analysis and writing the manuscript. All authors read and approved the final version.

\section{Funding}

This work did not have any funding support

\section{Availability of data and materials}

All data generated or analyzed during this study already exist in this published article.

Ethics approval and consent to participate

Not applicable.

Consent for publication

Not applicable.

Competing interests

The authors declare that they have no competing interests. 


\section{Author details}

${ }^{1}$ Pomology Department, National Research Centre, 33 El Bohouth St, Cairo 12622, Egypt. ${ }^{2}$ Horticulture Department Fac. of Agric., Ain Shams Univ., P.O. Box 68, Hadayek Shoubra, Cairo 11241, Egypt.

\section{Received: 13 March 2020 Accepted: 12 May 2020}

Published online: 29 June 2020

\section{References}

Abdel-Karim HA, Nehad MA, El-Rouby KM, Roshdy KA (2015) Effect of foliar application of boron and zinc on fruit set, yield and some fruit characteristics of Fuerte avocado. Res J Pharm, Biol Chem Sci 6(5):443-449

Alizadeh M, Sharifianjazi F, Haghshenasjazi E, Aghakhani M, Rajabi L (2015) Production of nanosized boron oxide powderby high-energy ball milling. Synthesis and Reactivity in Inorganic Metal-Organic and Nano-Metal Chemistry 45:11-14

Banat F, Pal P, Jwaied N, Al-Rabadi A (2013) Extraction of olive oil from olive cake using Soxhlet apparatus. American Journal of Oil and Chemical Technologies 4(1):2326-6570

Barker AV, Pilbeam DJ (2007) Handbook of plant nutrition. CRC Press/Taylor \& Francis Group, Boca Raton, FL, $632 \mathrm{pp}$

Basar H, Gürel S (2016) The influence of Zn, Fe and B applications on leaf and fruit absorption of table olive "Gemlik" based on phonological stages. ScientiaHorticulturae 198:336-343

Brown JD, Lilleland D (1946) Rapid determination of potassium and sodium in plant material and soil extract by flame photometer. Proc. Amer. Soc. Hort. Sci. 48:331-346

Chapman HD, Pratt PE (1961) Methods of analysis for soil, plant and water. Publication Universty of Calif., Davis, Division of Agric. Sci, p 309

Davarpanah S, Tehranifar A, Davarynejad G, Abadía J, Khorasani R (2016) Effects of foliar applications of zinc and boron nano-fertilizers on pomegranate (Punica granatum cv. Ardestani) fruit yield and quality. Scientia Horticulturae 210:57-64

Dhurve MK, Sharma TR, Bhooriya MS, Lodha G (2018) Effect of foliar application of zinc and boron on growth, reproductive and yield of pomegranate $\mathrm{CV}$. Ganesh in hast bahar. Int. J. Chem. Stud 6(5):499-503

Dible WT, Troug E, Berger HC (1954) Boron determination in soils and plants. Analytical Chemistry 26:403-421

Dieffenbacker A, Pocklington WD (1992) Standard methods for analysis of oils, fats and derivatives. Oxford Blackwell scientific publications, London, $1^{\text {st }}$ supplement to the $7^{\text {th }}$ edition, pp 1-151.

Duncan DB (1955) Multiple ranges and multiple tests. Biometrics 11:1-24

El-Hassanin AS, Saleh AL, Khater AM, Hussein MM, Hanan HA (2015) Effect of water requirements and organic fertilization on olive productivity and some leaves mineral content. Middle East J Agric Res 4(3):427-434

El-Metwally IM, Abo-Basha DMR, El-Aziz MEA (2018) Response of peanut plants to different foliar applications of nano- iron, manganese and zinc under sandy soil conditions. Middle East J Appl Sci 8(2):474-482

El-Sheikh MH, Khafgy SAA, Zaied SS (2007) Effect of foliar application with some micronutrients on leaf mineral content, yield and fruit quality of Florida prince desert red peach trees. J Agric Biol Sci 3:309-315

FAO (2010) Olive gap manual: good agricultural practices (GAP) for Near East and North Africa countries. Cairo, Egypt. 260 p. ISBN: 78- 92 - 51063484. http:// neareast.fao.org/Download.ashx?file=app_uploads/2383769/Files/Olive_Gap_ Manual.pdf

Fernandez ER, Gomez GV (1985) Cross-pollination in "Gordal Sevillana" olives. Hortscience 20:191-192

Gastal F, Lemaire G (2002) N uptake and distribution in crops: an agronomical and ecophysiological perspective. Journal of Experimental Botany. 53:789-799

Gharbi I, Issaoui M, Hammami M ( 2014) The Tunisian olive oil sector. OCL Oilseeds\& fats Crops and Lipids, Corps Gras, Lipides 21(2):1-6. (In French)D202.DOl:https://doi.org/10.1051/ocl/2013040. https://doi.org/10.1051/ ocl/2013040

Hikal ARF, Ibrahim MA, Abdelaziz RA (2017) Effect of different treatments of calcium and boron on productivity and fruit quality of navel orange fruits. Egyptian Journal of Horticulture 44(1):119-126

Jackson ML (1973) Soil chemical analysis, Constable and Co. Ltd. Prentice Hall of India Pvt. Ltd. New Delhi. pp. 10-114.

Jacobs MB (1959) The chemical analysis of food and products. D.Van. Nostrand Company, Inc, New York, pp 380-381
Jha Z, Behar N, Sharma SN, Chandel G, Sharma DK (2011) Pandey MP (2011) Nanotechnology: prospects of agricultural advancement. Nano Vision 1: 88-100

Keshavarz K, Vahdati K, Samar M, Azadegan B, Brown PH (2011) Foliar application of zinc and boron improves walnut vegetative and reproductive growth. HortTechnology 21(2):181-186

Kocakuşak S, Akçay K, Ayok T, Koöroğlu HJ, Koral M, Savaşçi ÖT, Tolun R (1996) Production of anhydrous, crystalline boron oxide in fluidized bed reactor. Chemical Engineering and Processing. 35(4):311-317

Mahmoud MR (2014) Response of Zaghloul date palms grown under Minia region conditions to spraying wheat seed sprout extract and nano- boron. Stem Cell 5(4):22-28

Marschner H (2012) Mineral nutrition of higher plants. Academic Press Limited Harcourt Brace and Company, Publishers, London, pp 347-364

Mohan K, Mandal BK, Naidu EA, Sinha M, Kumar KS, Reddy PS (2013) Synthesis and characterisation of flower shaped zinc oxide nanostructures and its antimicrobial activity, Sspectrochimica. Acta Part A: Molecular and Biomolecular Spectroscopy 104:171-174

Ojeda-Barrios DL, Perea-Portillo E, Hernández-Rodríguez OA, Martínez-Téllez J, Abadía J, Lombardini L (2014) Foliar fertilization with zinc in pecan trees. HortScience 49:562-566

Pereira JE, Urieta D, Menor A, Caño S, Barreal J , velasco MDM, Puentes R (2018) International olive growing: worldwide analysis and summary book.

Pregl F (1945) Quantitative organic micro analysis. 4 ${ }^{\text {th }}$ Ed. J.A. Churchill Ltd., London.

Saadati S, Moallemia N, Mortazavi SMH, Seyyednejad SM (2013) Effects of zinc and boron foliar application on soluble carbohydrate and oil contents of three olive cultivars during fruit ripening. Scientia Horticulturae 164:30-34

Saadati S, Moallemia N, Mortazavi SMH, Seyyednejad SM (2016) Foliar applications of zinc and boron on fruit set and some fruit quality of olive. Crop Res 51(1):1-5

Sayyad-amin P, Shahsavar AR, Aslmoshtaghi E (2015) Study on foliar application nitrogen, boron and zinc on olive tree. Trakia Journal of Sciences, No 2:131-136

Singh Y, Thakur N, Meena NK (2018) Studies on the effect of foliar spray of Zn, $\mathrm{Cu}$ and $\mathrm{B}$ on growth, yield and fruit quality of sweet orange (Citrus sinensis $\mathrm{L}$. ) cv. Mosambi. Int J Chem Stud 6(5):3260-3264

Snedecor GW, Cochran WD (1980) Statistical methods, 7th edn. the lowa State University Press, Ames, lowa, p 491

Venu A, Delvadia DV (2018) Effect of zinc, boron, and iron application on flowering and yield of acid lime (Citrus aurantifolia L) cv. Kagzi Lime. International Journal of Microbiological Research 10(4):1164-1165

Wettestien VD (1957) Chlorophyll lethal unjjer sub mink roskpische for minvechoel jerplastijen. Experimental Cell Research 12:427-433

Wild SA, Corey RB, Lyer JG, Voigt GK (1985) Soil and plant analysis for tree culture. Oxford and IBH Publishing Co., New Delhi, India, pp 1-142

\section{Publisher's Note}

Springer Nature remains neutral with regard to jurisdictional claims in published maps and institutional affiliations.

\section{Submit your manuscript to a SpringerOpen ${ }^{\circ}$ journal and benefit from:}

- Convenient online submission

- Rigorous peer review

- Open access: articles freely available online

- High visibility within the field

- Retaining the copyright to your article

Submit your next manuscript at $\boldsymbol{\nabla}$ springeropen.com 